\title{
KACAPI DALAM TEMBANG SUNDA CIANJURAN: KETERKAITANNYA DENGAN GAMELAN DEGUNG
}

\author{
Asep Nugraha \\ Prodi Karawitan Fak. Seni Pertunjukan \\ Institut Seni Budaya Indonesia (ISBI) Bandung \\ Email: kangasepnugraha@gmail.com
}

\begin{abstract}
Kacapi in tembang sunda cianjuran related to gamelan degung. Bonang melodies in gamelan degung were adopted by Kacapi Indung, and peking melodies in gamelan degung were adopted by kacapi rincik. This paper tries to explore the relationship by comparing the melodic between the kacapi instruments and the instruments in the gamelan gamelan degung. The result was kacapi in tembang sunda cianjuran as miniature of the gamelan degung performance.
\end{abstract}

Keywords: degung, kacapi, cianjuran.

\section{Pendahuluan}

Tembang sunda cianjuran merupakan musik yang lahir pada masa Priangan diduduki Belanda. ${ }^{1}$ Musik ini lahir di kabupatén Cianjur yang ketika itu merupakan ibu kota pemerintahan Karesidenan Priangan (Ace Hasan Su'eb, 1997:26). ${ }^{2}$ Tokoh di balik kemunculan musik ini adalah bupati Cianjur bernama Raden Aria Adipati (R.A.A.) Kusumaningrat (1834-1864) atau dikenal dengan sebutan Dalem Pancaniti yang membidani musik ini atas bantuan para nayaga lebet (Enip Sukanda, 1996:7; Su'eb, 1997:26).

Setelah kurang lebih enam tahun, R.A.A. Kusumaningrat dengan dibantu oleh para seniman lebet, berhasil menciptakan suatu bentuk seni baru, yang sumber asalnya dari seni pantun. Bentuk seni baru tersebut berorientasi kepada tata cara di lingkungan pedaleman. Dalam penyajiannya disesuaikan dengan tuntunan, tata cara, tata tertib, dan sopan santun para bangsawan pada masa tersebut (Su'eb, 1997:26).

Musik tersebut ditransimisikan secara 'tertutup' di kalangan arstokrat ${ }^{3}$ Cianjur atau kaum mé$n a k^{4}$ yang memiliki garis keturunan (terah) 'darah biru.' dinamai tembang pajajaran, sedangkan cara melantunkannya (menyanyikan) disebut mamaos (Su'eb, 1997:28). ${ }^{5}$ Seiring waktu musik ini dapat dinikmati serta dipelajari kaum ménak di luar 
'tembok istana' Kabupatén Cianjur, pertama kali terjadi pada saat kabupatén Cianjur dipimpin Bupati Demang Natakusumah (1910-1912). ${ }^{6}$

Pada saat jabatan bupati dipegang oleh Demang Natakusumah, beliau kurang memperhatikan para seniman 'kadaleman.' Karena itu para seniman mulai membawa seni mamaos ke luar padaleman dan mengajarkan kepada masyarakat, meskipun terbatas hanya untuk keturunan ningrat yang disebut ménak kaum (Su'eb, 1997:52).

Natakusumah diganti R.A.A.

H. Mucharam Wiranatakusumah yang mememerintah kabupatén Cianjur selama delapan tahun (19121920). Wiranatakusumah bukan keturunan bupati Cianjur, tetapi keturunan bupati Bandung yang menikahi puteri Prawiradiredja II (bupati Cianjur yang menggantikan Dalem Pancaniti). Wiranatakusumah merupakan sosok pemimpin yang sangat mengayomi dan menggemari kesenian (Natamihardja. 2009:36). Tidak heran, jika pada tahun 1921, ketika dilantik menjadi bupati Bandung mengantikan sang ayah, kesenian yang berada di Kabupatén Cianjur, yakni mamaos dan degung, turut serta dibawa Wiranatakusumah ke Bandung untuk dipelihara dan dikembangkan di lingkungan
Kabupatén Bandung (Su'eb, 1997:55; \& Natamihardja. 2009:36).

Peristiwa itu merupakan momentum, di mana mamaos 'mengepakan sayap' melewati batas geografis asal kelahirannya, yakni Cianjur. Di Bandung keberadaan mamaos atau tembang sunda cianjuran semakin populer, karena Wiranatakusumah memungsikan alat dan teknologi yang memudahkan akses bagi kesenian ini tampil di ruang publik yang luas, di antaranya melalui sejumlah rekaman audio dalam piringan hitam.

Salah satu media hiburan yang dimiliki pribumi yakni radio (ketika itu masih barang lux), digunakan Wiranatakusumah untuk mensosialisasikan musik ini ke hadapan khalayak ramai, menyajikan repertoar lagu yang masih 'asing' di telinga menjadi akrab dan menyebar ke berbagai penjuru wilayah keresidenan Priangan (Garut, Sumedang, Sukapura, Sukabumi, dsb.). Keberadaan seni mamaos diapresiasi sebagai seni yang menyajikan musikalitas berbeda dengan konvensi tembang yang telah ada (buhun). Semenjak itu musik tersebut mulai dijadikan fokus kajian para intelektual Sunda melalui sejumlah tulisan, ${ }^{7}$ diklasifikasikan sebagai tem- 
bang kaajeunakeun (kaayeunakeun), dan diberi istilah yang merepresentasikan Cianjur sebagai asal musik ini lahir, yakni tjiandjoeran (EYD: cianjuran). Penyebutan Cianjuran diamini Ganjar Kurnia yang menulis peranan radio NIROM (Nederland Indise Radio Omroep Maskape) Bandung pada tahun 1930-an, kerap menyiarkan mamaos dengan menyebut Tembang Cianjuran (Kurnia, 2003:49).

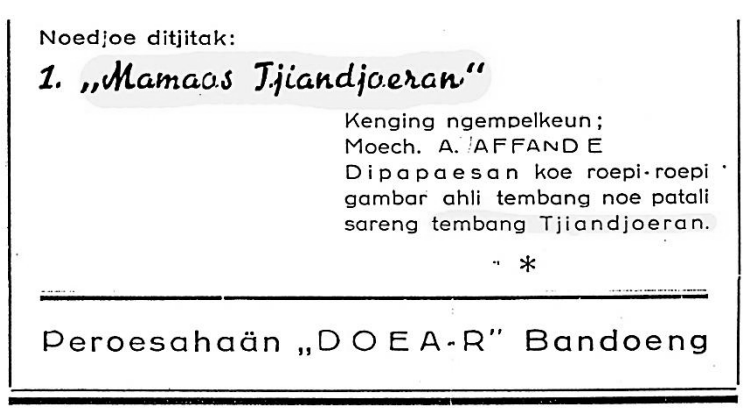

Gambar 2.1. Iklan buku tembang sunda cianjuran pada tahun 1948, ada dua istilah untuk menyebut kesenian yang dibawa R.A.A.H. Mucharam Wiranatakusumah dari Cianjur ke Bandung ini, yakni mamaos cianjuran dan tembang cianjuran (Dok. Asép Nugraha)

\section{Akhirnya Bandung menjadi} tempat yang menyokong tembang sunda cianjuran semakin subur membentuk komunitas masyarakat yang menjadi pendukung setia di wilayah Keresidenan Priangan. Istilah cianjuran lebih populer dibandingkan istilah tembang pajajaran atau mamaos. Ketika itu R. Emung Purawinata dalam pengantar buku Djaja
Swara Sunda (1948), menyebutkan bahwa tembang sunda cianjuran merupakan kesenian yang relatif baru untuk dikenal secara luas masyarakat, sehingga diklasifikasikan sebagai tembang kaayeunakeun (lagu-lagu 'sekarang' atau baru):

Saeutik katerangan lagoe Soenda teh aya 6 golongan: (1) golongan lagoe-lagoe tembang boehoen; (2) golongan lagoelagoe tembang kaajeunakeun (tjiandjoeran); (3) golongan lagoe-lagoe pantoen; (4) golongan lagoe-lagoe gamelan (roronggengan); (5) golongan lagoe-lagoe degoeng; (6) golongan lagoe-lagoe padalangan (kakawen sapoeratina) (Purawinata, 1948:4).

Terjemahan:

Sedikit informasi mengenai lagu Sunda yang terdiri atas enam golongan: (1) kelompok lagu tembang boehoen; (2) kelompok lagu tembang kaajeunakeun (tjiandjoeran); (3) golongan lagoe-lagoe pantoen; (4) golongan lagoe-lagoe gamelan (roronggengan); (5) golongan lagoe-lagoe degoeng; (6) golongan lagoe-lagoe padalangan (kakawen sapoeratina)).

\section{RRI Bandung Memperkenalkan Kacapi Rincik Ke Pelosok Jawa Barat}

Atas izin bupati Wiranatakusukmah, tembang sunda cianjuran dipancarluaskan NIROM (sekarang Radio Republik Indonesia (RRI) 
Bandung) agar keindahan musik ini dinikmati segenap lapisan masyarakat. Sedikit demi sedikit, terasa atau tidak terasa, hal itu membawa tembang pajajaran atau mamaos atau tembang sunda cianjuran, yang dulu di tempat asalnya (Cianjur) bersifat eksklusif karena diperuntukkan bagi kaum ménak, menjadi 'terbuka' dapat dinikmati oleh siapa pun yang menaruh minat terhadapnya. Atmosfir yang dinamis tersebut diikuti perkembangan instrumen pengiring yang bertambah dengan kehadiran kacapi rincik.

Kehadiran kacapi rincik ditelusuri penulis dengan membandingkan dua waktu penyajian tembang sunda cianjuran yang berbeda melalui dokumentasi poto yang merekam peristiwa pada dua masa. Masa yang pertama adalah saat Wiratanakusumah memboyong tembang sunda cianjuran dari Cianjur ke Bandung pada tahun 1921, penyajiannya masih diiringi kacapi parahu dan suling (peristiwa tersebut ditemukan dalam bukti poto pemain kacapi dan suling di pendopo 8 kabupatén Bandung tahun 1930-an). ${ }^{9}$

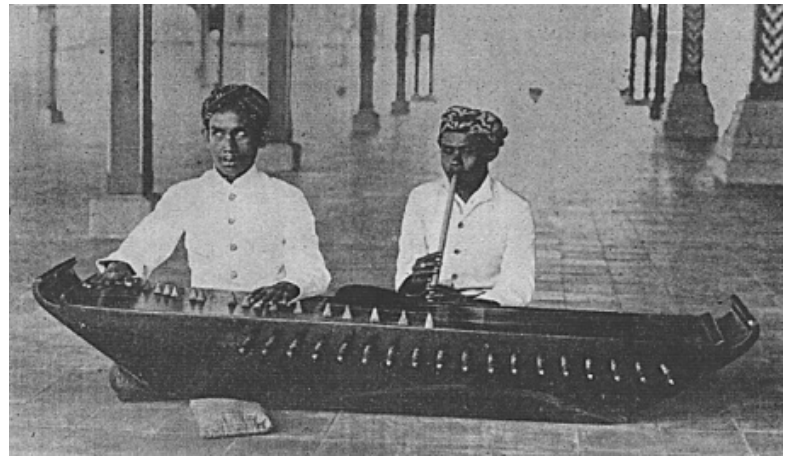

Gambar 2. Mang Uce, seniman lebet di kabupatén Bandung. Gambar poto menunjukan kacapi rincik belum ada dalam penyajian tembang sunda cianjuran (Dok. Enoch Atmadibrata)

Masa yang kedua adalah tatkala RRI Bandung dipimpin R.A. Darya yang menggunakan sandi asma (nama lain atau nickname) R.A. Mandala Kusumah sebagai ketua rombongan tembang sunda cianjuran mengisi siaran rutin di RRI Bandung (Sukanda, 1996:8), sajiannya telah dilengkapi dengan penambahan $\mathrm{ka}$ capi rincik. Ketika itu pemain kacapi indung adalah Tarya (Mang Tarya) murid juru kacapi kabupatian mang Ucé, pemain kacapi rincik adalah Uking Sukri (Mang Uking adalah murid mang Tarya), dan pemain suling adalah Mang Ono. 


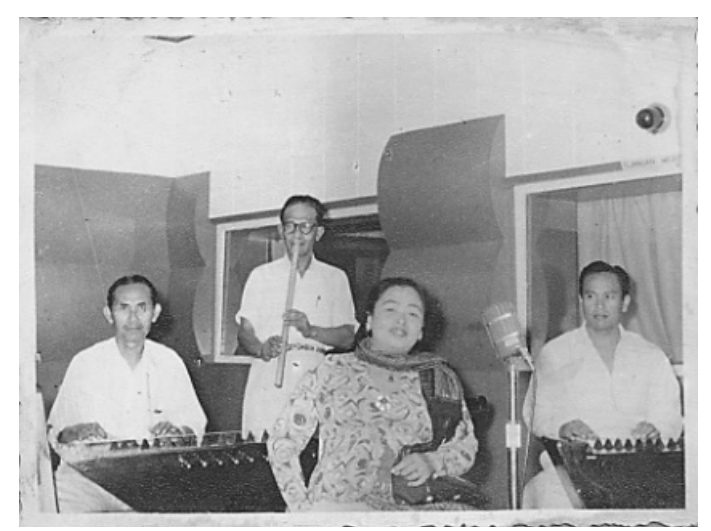

Gambar 3. Siaran tembang sunda cianjuran di RRI Bandung tahun 1955 sudah digunakan kacapi rincik. Dari kiri pemain kacapi indung, Mang Tarya (murid dari mang Uce), pemain suling Mang Ono, penembang ibu Saodah, dan pemain kacapi rincik adalah Mang Uking (Dok. Enoch Atmadibrata)

Fenomena kemunculan kacapi rincik yang sebelumnya tidak pernah ada dalam penyajian tembang sunda cianjuran juga ditelusuri Enip Sukanda dalam buku Kacapi Sunda (1996). Penelusuran Sukanda dilakukan dengan mencermati rekaman piringan hitam. Penelusurannya itu ditulis dalam buku Kacapi Sunda (1996) sebagai berikut:

Jika kita mendengarkan rekaman cianjuran dalam piringan hitam sekitar tahun 20-an, iringan musiknya hanya terdiri dari kacapi indung dan suling saja. Penambahan $k a-$ capi rincik berlangsung sekitar tahun 50-an, yaitu tatkala RRI Bandung dipimpinan RA. Darya dengan nama samaran untuk kedudukannya sebagai pimpinan tembang Sunda RA. Mandalakusumah (Sukanda, 1996:8).
Keberadaan radio - khususnya RRI Bandung - signifikan berkontribusi dalam menyebarkan tembang sunda cianjuran ke wilayah Priangan beserta perubahan yang terjadi di dalamnya, termasuk kehadiran kacapi rincik sebagai instrumen yang baru diintegrasikan pada tahun 1950. Seiring waktu setiap seniman daerah yang mengapresiasi RRI Bandung, mulai mengintegrasikan kacapi rincik dalam pertunjukan tembang sunda cianjuran. Akhirnya mengkristal dan tersimpan dalam ruang dan waktu, sehingga kacapi rincik dalam tembang sunda cianjuran eksis hingga sekarang.

Penyajian tembang sunda cianjuran pada lagu bermetrum tetap (tandak) - seperti panambih dan dedegungan dari repertoar degung klasik - tidak dilengkapi melodi tabuhan kacapi rincik menimbulkan kesan 'kurang lengkap'. Terasa génjlong (timpang) atau ada yang hilang seperti ungkapan paribasa Sunda: kawas pantun teu jeung kacapi. Kini musikalisasi kacapi rincik mendapat sorotan penting karena berkontribusi menciptakan jalinan musik tembang sunda cianjuran menjadi lebih indah 
Pengakuan tersebut semakin signi-fikan, setelah komunitas masyarakat pendukung tembang sunda cianjuran mengukuhkan keberadaan kacapi rincik dan senimannya untuk 'diper-hitungkan' dan mendapatkan apre-siasi melalui festival atau pasanggiri. Seniman dari kota Bandung yang berhasil mendudukan diri sebagai pemain kacapi rincik terbaik pada pasanggiri tingkat Jawa Barat di antaranya Nana Suhana (Alm), Ah-mad Suwandi (Alm), Dédé Supar-man, dan Galih.

Istilah Rincik untuk Kacapi Kecil pada Tembang Sunda Cianjuran

Nama rincik untuk instrumen kacapi yang berukuran kecil pada penyajian tembang sunda cianjuran masih 'misteri.' Selama penulis mengumpulkan data di lapangan dan studi beberapa literatur belum ditemukan jawaban memuaskan. Mau tidak mau, suka atau pun tidak suka bahasan mengenai istilah rincik dirasakan penting untuk dituliskan dalam kajian. Mudah-mudahan keterbatasan uraian penulis ini memberi konklusi awal bagi penelusuran selanjutnya, terutama bagi peneliti yang menaruh minat untuk melanjutkan penelitian kacapi rincik pada tembang sunda cianjuran.
Ubun Kubarsah dalam buku Waditra (1994), menafsirkan istilah rincik untuk kacapi yang berukuran kecil dalam penyajian tembang sunda cianjuran dengan pendekatan kirata (Sunda; dikira-kira tapi nyata), yakni rincik = hujan nu ngaririncik (bahasa Indonesia: hujan rintik rintik) (Kubarsah, 1994:18). Pernyataan tersebut bagi penulis yang menekuni kacapi rincik dan kacapi indung, dapat menangkap maksud Kubarsah memberikan definisi tersebut. Daya khayal tertuju pada ritmis air hujan yang turun membasahi bumi (biasanya tidak deras) diasosiasikan dengan ritmis tabuhan yang dibawakan kacapi ukuran kecil tersebut. Namun bagi orang awam pendefinisian Kubarsah dapat membuat bingung dan mungkin mempertanyakan hubungan fenomena hujan dengan kacapi ukuran kecil dalam tembang sunda cianjuran.

Pendekatan kirata menimbulkan hasil yang multitafsir karena pendekatan epistemilogis tersebut dilakukan dengan cara dicocokcocokan. Setiap orang bisa saja berbeda penafsirannya karena kental dengan 'aroma' subjektifitas. Hal ini dicontohkan Asép Wahyudin: "bisa saja saya mendefinisikan rincik berdasarkan pengalaman pribadi seba- 
gai tukang ngadu jangkrik, sehingga mendefinisikan rincik dengan kirata "ting tirilik jiga sora jangkrik," karena instrumen tersebut menghasilkan bunyi nada pada wilayah oktaf petit (tinggi)" (wawancara Asep Wahyudin). Pada kesempatan yang sama Heri Heridini menggambarkan pendekatan kirata yang harus disikapi peneliti secara hati-hati:

Orang Sunda memang terbiasa menggunakan kirata dalam memberikan nama: Misro (amis di jero), Combro (oncom dijero), Korsi (cokor disisi). Untuk nama manusia, misalnya Suhadma dan Misnem yang pada masa lampau berhubungan dengan identitas dan informasi si anak dilahirkan (identifikasi karena banyak anak banyak rejeki), Suhadma = Subuh Ahad jam Lima; Misnem = Kemis Nem. Kirata akan menjadi sesat jika dicocokcocokkan oleh orang yang tidak paham asal-usul pemberian nama itu, seperti Rincik = hujan ngaririncik atau tingtirilik jiga sora jangkrik, apakah betul diterjemahkan seperti itu? Penerapan Kirata atau disebut akronim dalam bahasa Indonesia, harus logis dan tidak terbantahkan. Contoh Kirata yang logis dalam kesenian di Jawa Barat antara lain: Tarling sebagai akronim (kirata) dari gitar dan suling; bangréng akronim dari terbang dan ronggéng; dan bangklung sebagai akronim terbang dan angklung. Pendefinisian tersebut tidak terbantahkan, karena memang defi- nisi tersebut sesuai dengan realita yang terjadi di lapangan (wawancara Heri Herdini, tanggal 14 Juni 2016).

Pernyataan rincik sebagai akronim hujan ngaririncik dibantah oleh Kubarsah dalam buku yang sama. Pada bagian berbeda $\mathrm{Ku}-$ barsah menelusuri arti rincik dengan peluruhan kata yakni rincik menjadi 'cilik', atau kacapi rincik adalah kacapi cilik. Pernyataan kedua Kubarsah ini mendekati realita, karena ukuran kacapi rincik lebih kecil dibandingkan kacapi parahu (indung). Namun pendefinisian tersebut meninggalkan kesan 'pemaksaan' karena kata dasar menjadi berubah. ${ }^{10}$ Kesan pemaksaan tersebut semakin nyata ketika istilah 'cilik' tidak ditemukan pada sejumlah buku Kamus Basa Sunda.

Penulis mendapat sudut pandang berbeda ketika menanyakan istilah kacapi rincik kepada Dede Suparman sebagai objek seniman yang dikaji sebagai nara sumber dalam tulisan ini. Sumber informasi dari Suparman dirasakan tepat karena yang bersangkutan bekerja di RRI Bandung, yakni instansi yang menjadi media dalam mensosialisasikan kacapi rincik di Jawa Barat melalui siaran tembang sunda cian- 
juran pada tahun 1950-an. Di samping itu Suparman belajar kacapi rincik kepada mang Uking Sukri, di mana Sukri adalah pemain kacapi rincik RRI Bandung yang menjadi pelaku saat menyosialisasikan kacapi rincik pada tahun 1950.

Kasauran Mang Uking, mimiti pisan ayana kacapi rincik dimaenkeun dina lagu-lagu ekstra (panambih). Kulantaran lalaguan ekstra teh can jiga ayeuna, masih saperti lagu cimplung atawa Banjaran, nu ngamelodi, nya takol kacapi rincik saukur ngemprangan teu beda jeung tabeuhan waditra rincik dina gamelan. Dumasar kana tabeuhan rincik gamelan nu diterapkeun, nya kaluar babasaan "sok ah rincikan jang." Kabiasaan babasaan eta nu jadi cukang lantaran kunaon eta kacapi disebut kacapi rincik.

Terjemahan:

Mang Uking pernah mengatakan bahwa pertama kali munculnya kacapi rincik dimainkan pada lagu ekstra (panambih). Lagu-lagunya belum seperti sekarang, masih seperti lagu Cimplung atau Banjaran yang bermelodi, maka tabuhan kacapi rincik hanya ngemprangan seperti tabuhan waditra rincik pada gamelan. Berdasarkan itu, muncul pernyataan yang menjadi kebiasaan "ayo rincikan." Kebiasaan itu yang kemudian menjadi identitas terhadap instrumen tersebut sehingga disebut kacapi rincik.
Pernyataan Suparman di atas memberikan gambaran bahwa penyebutan kacapi rincik merupakan dampak dari garap tabuhan instrumen tersebut, yang mengadopsi tabuhan rincik pada gamelan. Akhirnya penyebutan rincik untuk kacapi berukuran kecil tersimpan dalam perjalanan ruang dan waktu. Hal itu bertahan meskipun garap permainan kacapi indung (kacapi berukuran besar) berkembang dengan munculnya tabuhan kait pada lagu panambih, dan permainan kacapi rincik menerapkan tabuhan alternatif lain yang disebut gumekan. Tabuhan ini berbeda dengan garap tabuhan kemprangan yang diterapkan kacapi rincik pada awal kemunculannya yang mengadopsi tabuhan rincik pada gamelan. Gumekan memberikan keleluasaan bagi pemain $\mathrm{ka}$ capi rincik memainkan melodi dengan cara mengikuti kontur melodi vokal jika sajian berbentuk sekar gending, dan mengikuti kontur melodi suling jika disajikan instrumental.

Kesimpulan dari bahasan pada Subbab ini, untuk sementara penulis 'condong' megikuti informasi yang diberikan Suparman, karena memberikan alur yang dapat dicermati akal dan pikiran (logis). Terle- 
pas jika pada perkembangannya permainan tabuhan kacapi rincik tidak lagi mengadopsi waditra rincik pada gamelan. Nama rincik pada kacapi ukuran kecil dalam tembang sunda cianjuran melembaga dan mentradisi secara turun-temurun sehingga tetap digunakan hingga sekarang. Tidak ada di antara seniman tembang sunda cianjuran yang mencoba untuk merubahnya.

\section{Hubungan Kacapi Rincik dan Kacapi Indung dengan Gamelan Degung}

Bupati Bandung Wiranatakusumah mensosialisasikan kesenian selain tembang sunda cianjuran, yang dibawanya dari Kabupatén Cianjur, yakni gamelan degung. Repertoar lagu klasik yang dibawa dari Cianjur dikembangkan sehingga jumlahnya semakin bertambah dengan adanya seniman lebet yang aktif pada masa itu, antara lain Mang Idi yang menjadi lurah nayaganya. ${ }^{11}$

Keberadaan gamelan degung disenyalir mempengaruhi garap tabuhan instrumen pada tembang sunda cianjuran, khususnya gending berbentuk sekar alit yang memperkaya garap tabuhan kacapi indung dan kacapi rincik pada iringan lagu panambih. Perubahan tersebut telah disinggung pada subbab sebelumnya, yakni munculnya tabuhan kait pada kacapi indung dan tabuhan gumekan pada kacapi rincik.

Tabuhan kait pada kacapi indung mengadopsi secara percis tabuhan bonang pada gamelan degung (seperti dicontohkan notasi di bawah ini).

Notasi Tabuhan bonang pada lagu Catrik

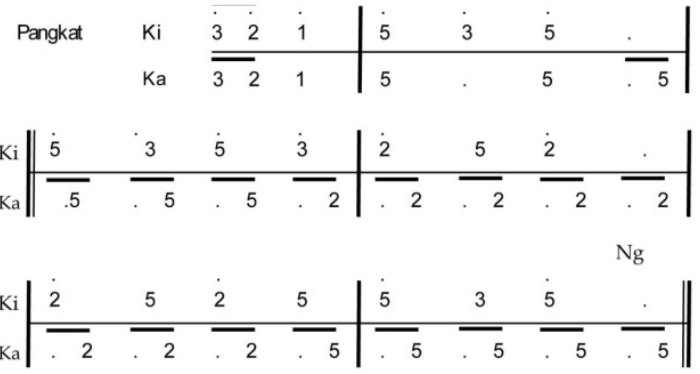

Notasi tangan kanan Tabuhan kacapi indung pada lagu Catrik
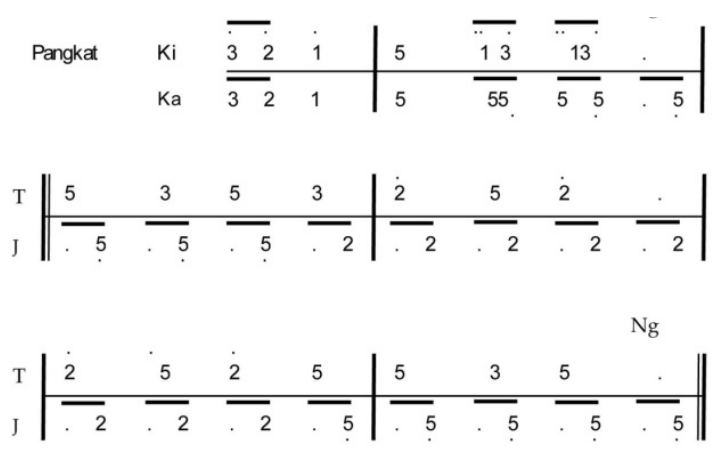

Kedua tabuhan di atas (antara bonang dengan kacapi indung) identik memainkan melodi yang sama, meskipun pada matra ke-1 dan ke-4 melodi yang dimainkan berbeda 1 
(satu) oktaf. Permainan bonang menerapkan tangan kanan (Ka) dan kiri (Ki), sedangkan kacapi indung menerapkan tangan kanan dengan pengaplikasian jari telunjuk (T) dan jari jempol (J). Pengimplementasian teknik yang berbeda dikarenakan bonang ditabuh dengan cara dipukul, sedangkan kacapi indung dimainkan dengan cara dipetik. Selain itu timbre bunyi logam yang dihasilkan bonang dan dawai kacapi berbeda intensitasnya.

Tabuhan kacapi indung yang mengadopsi bentuk permainan bonang degung melahirkan tabuhan yang disebut kait. Penamaan tersebut akibat jari jempol dan telunjuk yang bergerak bergantian membunyikan nada yang berbeda oktaf, menghasilkan gerak jari seperti mencongkel (Sunda: kait). Peristiwa itu yang mendasari lahirnya istilah kait sebagai tabuhan yang baru pada permainan kacapi indung, sedangkan cara menabuhnya disebut dikait, digunakan untuk iringan lagu panambih hingga sekarang.

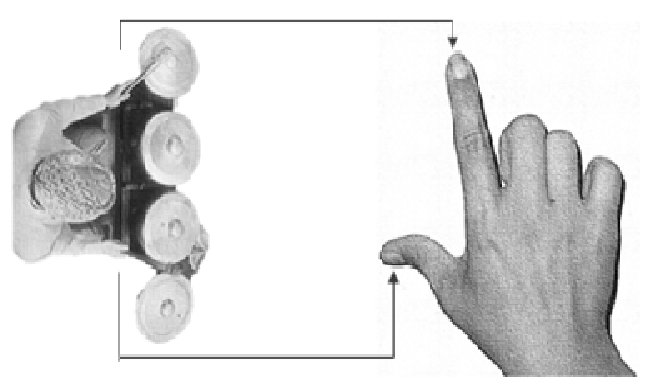

Gambar 4. Permainan tangan kanan dan kiri pada tabuhan bonang gamelan degung diadopsi dengan penerapan jari jempol dan telunjuk pada permainan kacapi indung dalam iringan lagu panambih.

Garap tabuhan bonang pada gamelan degung mempengaruhi permainan kacapi indung dalam sajian lagu panambih, tentunya diikuti penyesuaian instrumen chordophone lain dalam tembang sunda cianjuran, yakni kacapi rincik yang beradaptasi mengimbangi musikalitas tabuhan kait dari instrumen kacapi indung. Penulis mengidentifikasi melodi kacapi rincik ternyata mirip dengan permainan saron peking pada gamelan degung. Hubungan tersebut diamati melalui perbandingan notasi berikut ini.

Tabuhan saron peking pada lagu Catrik

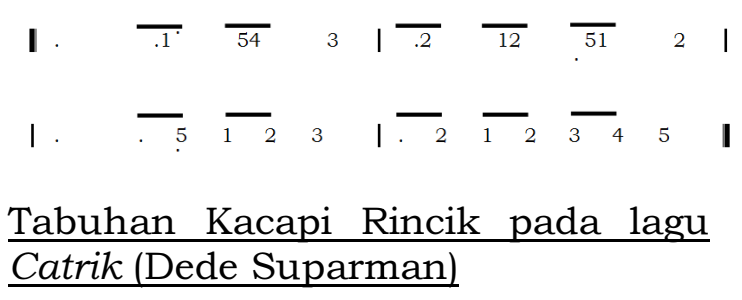




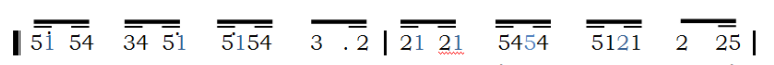

$|\overline{\overline{1232}} \overline{\overline{1515}} \quad \overline{\overline{1232}} \quad \overline{\overline{345 i}}| \overline{\overline{5154}} \quad \overline{\overline{3232}} \quad \overline{\overline{3454}} \quad \overline{5 \overline{51}} \mid$

Kedua melodi tabuhan di atas dimainkan dengan cara berbeda: saron peking ditabuh dengan cara dipukul menggunakan alat yang dipegang oleh tangan kanan, sedangkan kacapi rincik dimainkan dengan menggunakan kedua tangan menggunakan teknik disinteruk untuk tangan kanan dan ditoel untuk tangan kiri. Kedua teknik tabuhan kacapi rincik tersebut melembaga dan menjadi konsensus yang belum tergantikan hingga sekarang.
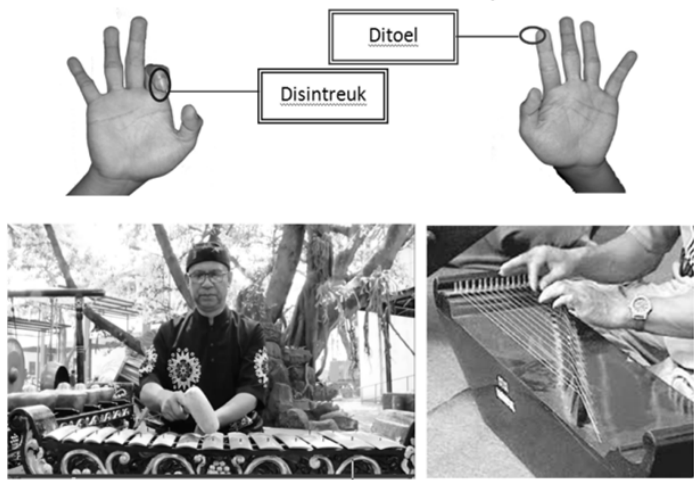

Gambar 5. permainan saron peking pada gamelan degung diadopsi permainan kacapi rincik dengan menerapkan dua jemari tangan yang menerapkan teknik disintreuk dan ditoel

Perbandingan dua notasi sebelumnya hanyalah cuplikan permainan saron peking dan kacapi rincik dalam satu periode (1 kali goongan). Pada praktiknya ada banyak varian melodi yang dimainkan (khususnya pada kacapi rincik). Namun untuk contoh notasi tabuhan di atas, penulis sengaja menggambarkan saron peking dan kacapi rincik gaya Dédé Suparman yang ternyata memiliki persamaan dalam hal kontur melodi.

Adapun Kontur melodi pada lagu Catrik yang dibawakan saron peking dan kacapi rincik, sesuai dengan notasi yang dituliskan di atas, digambarkan notasi tablatur berikut:

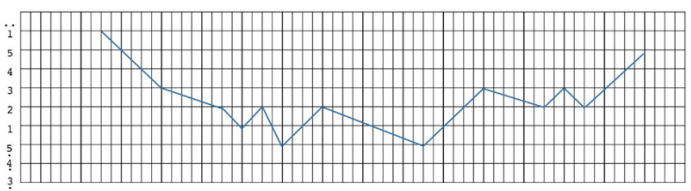

Notasi tablatur saron peking lagu Catrik

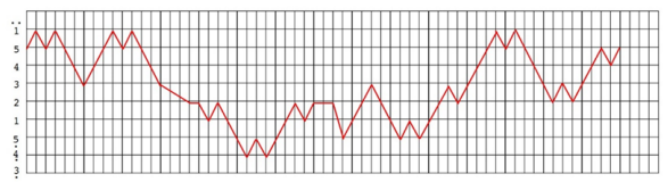

Notasi tablatur kacapi rincik lagu Catrik

Kontur melodi yang dibangun kacapi rincik dan saron peking pada dua notasi tablatur di atas dalam satu periode (1 goongan), menghasilkan perbandingan kontur melodi berikut ini.

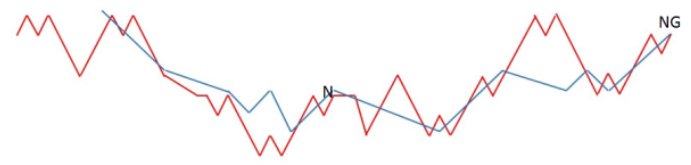

Gambar 6. Perbandingan kontur Melodi antara saron peking dan kacapi rincik pada lagu Catrik dalam satu goongan. 
Kontur melodi kacapi rincik memainkan variasi yang lebih kompleks. Meskipun berbeda varian dengan saron peking, tetapi teridentifikasi ada patokan yang senantiasa diikuti oleh kedua instrumen dalam membangun melodi. Patokan tersebut adalah pijakan pada nada kenongan dan goongan yang senantiasa ditabuh pada nada yang sama, digambarkan oleh arkuh berikut:

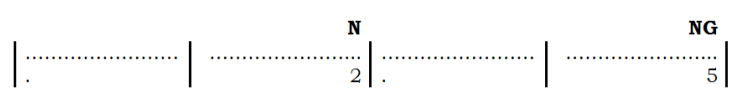

Keterangan:

$$
\begin{aligned}
& \mathrm{N}=\text { Kenongan } \\
& \mathrm{NG}=\text { Goongan }
\end{aligned}
$$

Penulis menelusuri tabuhan kacapi rincik dan peking degung pada lagu berbentuk sekar ageung, di mana melodi kacapi rincik dan peking degung relatif sama. Hal itu disebabkan melodi kacapi rincik dan saron peking disusun oleh jalinan nada yang dalam satu ketukan, maksimal bisa terdiri atas empat nada.

Untuk menunjukkan persamaan tersebut, penulis mimilih sampel lagu Pajajaran Degung yang dinotasikan Entjar Tjarmedi, di mana notasi tabuhan saron peking dibandingkan dengan kacapi rincik gaya Dédé Suparman, untuk kemudian diperbandingkan dalam rangka mencari kesamaan melodi yang menyusunnya. Adapun dalam tulisan ini lagu Pajajaran Degung yang menjadi contoh dibatasi 6 matra, sebagai sampel yang menunjukan kesamaan melodi saja

Notasi Kacapi Rincik pada lagu Pajajaran Degung (matra 1-6)

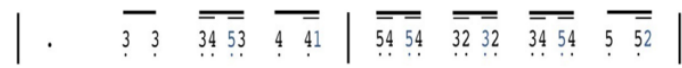

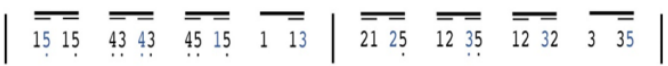

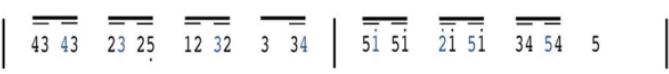

Melodi tabuhan kacapi rincik di atas apabila dituliskan ke dalam notasi tablatur akan didapatkan kontur melodi sebagai berikut:

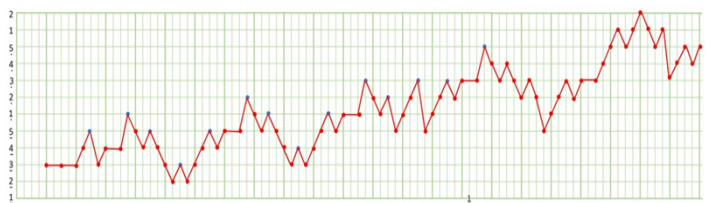

Gambar 7. Kontur melodi kacapi rincik lagu Degung Pajajaran dari Matra 1- 6.

\section{Penutup}

Kacapi dalam tembang sunda cianjuran dalam aspek permainannya ternyata merupakan pengadopsian instrumen pada gamelan degung, khususnya pada waditra bonang dan peking. Pola permainannya relatif sama walaupun ditemukan usaha pengembangan 
dari para seniman penyaji kacapi dalam tembang sunda cianjuran. Namun tetap saja ditemukan ensensi dari persamaan kontur melodi yang disajikan antara kacapi dalam tembang sunda cianjuran dan instrumen yang diadopsi dari gamelan degung.

\section{CATATAN AKHIR}

1 Priangan merupakan hadiah Mataram untuk Belanda yang membantu memenangkan perang suksesi. Dalam perebutan tahta kerajaan Mataram, Pangeran Puger dibantu Belanda menang dan dinobatkan sebagai sunan Mataram dengan gelar Susuhunan Paku Buwono I, walau harus membayar mahal atas bantuan Belanda, dengan menyerahkan wilayah Priangan, Cirebon, Madura bagian Timur kepada Belanda (Anhar, 2012:98)

Keresidenan Priangan lahir pada era Raffles dan dibentuk melalui resolusi pada tanggal 13 Februari 1813. Cianjur menjdi ibu kota Karesidenan Priangan. Namun pada tahun 1856, ibu kota karesidenan Priangan dipindahkan ke Bandung karena letusan dasyat Gunung Gede yang menghancurkan wilayah Cianjur (Kunto, 1996:55)

${ }^{3}$ Aristokrat adalah orang dari golongan bangsawan atau ningrat (Pusat Bahasa, 2008: 90).

${ }^{4}$ Istilah Ménak dalam Kamus Bahasa Indonesia yang diterbitkan Departemen Pendidikan Nasional adalah orang terhormat, bangsawan, atau keturunan Raja (Pusat Bahasa, 2008:938).

${ }^{5}$ Masyarakat Sunda yang berada pada stratifikasi sosial level bawah (Sunda: cacah), tidak dapat menikmati apalagi mempelajari musik ini. Kondisi saat itu seperti penggambaran babasan Sunda: cacah rucah atah warah atau dalam bahasa Indonesia: rakyat berbeda kelas dengan kaum ménak (Nugraha, 2012:76). Babasan tersebut memperlihatkan pemilahan antara ménak dengan cacah yang dikondisikan oleh situasional jaman kolonial dan kultur feodal yang mendikotomikan masyarakat ke dalam kasta atas dan bawah, berdampak pada seluruh aspek kehidupan, termasuk jenis musik atau seni yang dapat dinikmati oleh mereka (ménak dan cacah)

${ }^{6}$ Demang Natakusumah memerintah Cianjur selama dua tahun, mengisi kevakuman pemerintahan karena Bupati sebelumnya, R.A.A. Prawiradiredja II, tidak memiliki keturunan laki-laki (Su'eb, 1997:52).

${ }^{7}$ Pada masa itu kaum intelektual Sunda mulai memberikan perhatian khusus pada tembang sunda cianjuran seperti R. Satjadibrata menelorkan buku Rusiah Tembang dan juga Moech. A. Affande yang menyusun buku Djaya Swara Soenda (1948) yang didalamnya ditemukan iklan mengenai buku cianjuran yang tengah menjadi fokus perhatian pada masa itu.

8 Pendopo pada jaman para Bupati Priangan, merupakan bangunan terbuka pada serambi depan dari kabupaten sebagi tempat pusat kebudayaan dan pesta keluarga bangsawan (Wiradiredja, 2014:29).

9 Poto tersebut adalah seniman kacapi bernama Mang Ucé, tuna netra yang menjadi leluhur seniman kacapi dalam tembang sunda cianjuran di kabupatén Bandung, karena keberadaan permainan kacapi pada tembang sunda cianjuran yang teraktualisasikan dewasa ini bersumber dari Mang Ucé yang mentransmisikan skill kepada generasi di bawahnya. Selanjutnya murid-muridnya itu menyebarkan kembali kepada generasi selanjutnya (Nugraha, 2007:97)

10 Dalam bahasa Sunda biasanya peluruhan kata tidak menyebabkan perubahan makna atau arti secara radikal. Contoh colok menjadi nyolok, tonjok menjadi nonjok, cabut menjadi nyabut. Tatanan kata dasarnya tidak berubah drastis seperti rincik dengan $c i[l] i k$.

${ }^{11}$ Penulis mendapatkan informasi dalam perkuliahan bahwa repertoar lagu-lagu degung klasik digunakan sebagai iringan film Lutung Kasarung oleh bupati Wiranatakusumah. Hal itu indikasi bahwa gamelan degung juga menjadi primadona seni yang ditawarkan bupati Bandung ini. 


\section{DAFTAR PUSTAKA}

Affande. Moech. A. 1948. Djaja Swara Soenda. Bandung: Dua D

Anhar, Ratnawati. 2012. Untung Surapati. Jakarta: Kementerian Pendidikan dan Kebudayaan Direktorat Sejarah dan Nilai Budaya.

Kunto, Haryoto. 1996. Semerbak Bunga di Bandung Raya. Bandung: PT. Granesia.

Pusat Bahasa. 2008. Kamus Besar Bahasa Indonesia. Jakarta: Departemen Pendidikan Nasional.

Nugraha, D. 2012. Ngamumule Basa Sunda: 1200 Paribasa jeung Babasan Sunda Pikeun SD jeung $S M P$. Bandung: Yrama Widya.

Su'eb, Ace Hasan. 1996. Wawasan Tembang Sunda, Bandung: Geger Sunten.

Sukanda, Enip. Kacapi Sunda. Jakarta: Ditjen Kebudayaan Depdikbud.

Wiradiredja, Mohamad Yusuf. 2014. Tembang Sunda Cianjuran di Priangan (1834-2009): Dari Seni Kalangenan sampai Seni Pertunjukan. Bandung: Sunan Ambu Press. 